\title{
Pneumologia
}

\section{Disseminated Mycobacterium tuberculosis following renal transplant: A case report}

Mahmoud Sadeghi-Haddad-Zavareh¹, Mohammad Reza Hasanjani Roushan', Zeinab Mohseni Afshar², Masomeh Bayani Soheil Ebrahimpour ${ }^{1}$, Shahab Saeedi ${ }^{1}$, Arefeh Babazadeh $^{1, *}$

${ }^{1}$ Infectious Diseases and Tropical Medicine Research Center, Health Research Institute, Babol University of Medical Sciences, Babol, I.R. Iran

${ }^{2}$ Clinical Research Development Center, Imam Reza Hospital, Kermanshah University of Medical Sciences, Kermanshah, Iran

Abstract

English:

Miliary tuberculosis (TB) presents a major challenge following a renal transplant in humans. In the current report, we described a patient with disseminated TB following renal transplantation. The article presents the case of a 38-year-old man who presented an 8-month history of fever, chills, sweating, low-back pain and significant weight loss. Chest radiography and computed tomography (CT) scan showed miliary nodules distributed in the two lungs. The transbronchial lung biopsy revealed a granulomatous reaction with caseous necrosis. Magnetic resonance imaging (MRI) of the brain found multiple tuberculomas. Also, MRI of the lumbosacral was indicative of a psoas abscess. Therefore, miliary pulmonary, cerebral and spinal TB was confirmed. The patient was started on an anti-TB regimen and paravertebral aspiration was also done. The patient's condition improved considerably. In conclusion, this case report can remind us of the importance of maintaining a high clinical suspicion and performing a thorough workup to establish a timely diagnosis and treatment of miliary TB.

Keywords

Mycobacterium tuberculosis $\bullet$ renal transplant $•$ miliary tuberculosis

\section{Infectie diseminata cu Mycobacterium tuberculosis post transplant renal: prezentare de caz}

Rezumat

Romanian:

Tuberculoza miliară (TB) prezintă o provocare importantă după transplantul renal. Descriem în lucrarea prezentă un pacient cu tuberculoză diseminată în urma transplantului renal. Prezentam cazul unui pacient de 38 de ani cu debut de 8 luni de febră, frisoane, transpirații, dureri de spate, și pierderea semnificativă în greutate. Radiografia toracică și tomografia computerizată (CT) au arătat noduli miliari distribuiți în ambii plămâni. Examenul anatomopatologic a relevat o reacție granulomatoasă cu necroză cazeoasă. RMN cerebral a dezvăluit tuberculoame multiple, iar cel lombosacrat a dezvăluit abces la nivelul psoasului. S-a initiat tratament antituberculos si aspiratie paravertebrala cu evolutie clinica favorabila. În concluzie suspiciunea de TB trebuie sa ramana ridicata la pacientii imunsupresati în tarile endemice.

Cuvinte-cheie

Mycobacterium tuberculosis • transplant renal • tuberculoză miliră

\section{Introduction}

Opportunistic infections are known to be serious threats in transplanted recipients (1). Such recipients will be susceptible to infection due to immunosuppressive therapy. Also, Mycobacterium tuberculosis (TB) is a major and common infection after a solid organ transplant (SOT), particularly in areas where TB is endemic (2). Many studies had confirmed an increased risk of active TB after SOT (3). About $15 \%$ of post-renal transplant cases with TB develop extrapulmonary as miliary TB with a mortality rate of $30 \%(2,4)$.

Miliary TB may be very atypical and non-specific regarding clinical features, particularly in kidney transplant recipients, making the diagnosis difficult. Here, we describe a renal transplant recipient who developed miliary TB with multiple organ involvement: lung, brain and spine.

${ }^{*}$ Corresponding author: Arefeh Babazadeh

E-mail: drbabazadeh.a@yahoo.com

ว Open Access. (c) 2021 Sadeghi-Haddad-Zavareh et al., published by Sciendo (c) BY-NC-ND This work is licensed under the Creative Commons Attribution-NonCommercial-NoDerivs 4.0 License. 


\section{Case presentation}

We present a case of a 38-year-old man with an 8-month history of fever, chills, sweating, low-back pain and significant weight loss.

The patient presented a kidney transplant 6 years ago, being under immunosuppressive treatment with cyclosporine and prednisolone. The patient is also diagnosed with spondylodiscitis based on the results of the lumbosacral magnetic resonance imaging (MRI) that he previously performed for his progressive low-back pain. On admission, there were no significant findings on the physical examination. Laboratory findings were: haemoglobin level of $137 \mathrm{~g} / \mathrm{L}$ and white blood cell (WBC) counts 7200 cells $/ \mathrm{mm}^{3}$ with $72 \%$ polymorphonuclear leukocyte. The renal profile was within the normal range, but a slightly increased level of alanine aminotransferase (ALT) was detected. The C-reactive protein (CRP) was $15 \mathrm{mg} / \mathrm{dL}$ and the erythrocyte sedimentation rate (ESR) was $103 \mathrm{~mm} / \mathrm{h}$. The chest X-ray (CXR) was normal. Sputum culture was not performed because the patient had no cough. Given the systemic persistent symptoms, the immunocompromised status and the presence of spondylodiscitis modification and Pott's disease were suspected. The patient underwent a lumbar biopsy and antiTB therapy was started. After 6 weeks, the histopathological and bacteriological results from the lung biopsy specimen showed no evidence of TB. Despite a slight improvement in symptoms, the anti-TB treatment was discontinued.

The patient was re-admitted after several weeks with the same set of complaints as previous ones. The physical examination and paraclinical findings were similar. This time a pyogenic spondylodiscitis was suspected and a large spectrum of antibiotics were administered. Also, a repeated biopsy of the affected spinal bones was negative for TB. During hospitalisation, his general status altered. The patient developed respiratory symptoms. CXR and computerised tomography (CT) scans showed distributed miliary nodules in both lung fields (Figures 1 and 2) consistent with miliary TB. Bronchoscopy with bronchoalveolar lavage (BAL) and transbronchial biopsy of the lung were carried out. The pathological examination found a granulomatous reaction with caseous necrosis (Figure 3). Therefore, miliary pulmonary TB has been confirmed. Treatment for TB was initiated with rifampicin $(10 \mathrm{mg} / \mathrm{kg} /$ day), isoniazid $(5 \mathrm{mg} / \mathrm{kg} /$ day), ethambutol (25 mg/kg/day), pyrazinamide (15 mg/ $\mathrm{kg} /$ day) and pyridoxine $(10 \mathrm{mg} /$ day $)$. During treatment, the patient developed headache, nausea and vomiting. The MRI of the brain revealed multiple tuberculomas (Figure 4) and systemic corticotherapy was initiated. Given the extension of the back pain to the lower limbs, a new MRI was performed and it revealed a psoas abscess. Therefore, paravertebral aspiration has been done. The polymerase chain reaction

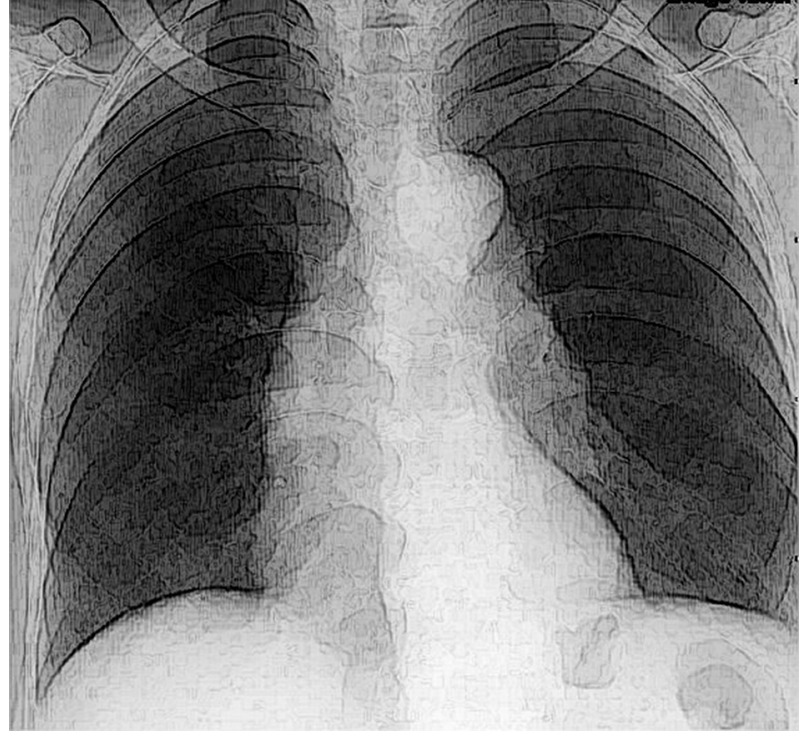

Figure 1. Chest radiography revealing distributed miliary nodules in both lung fields.

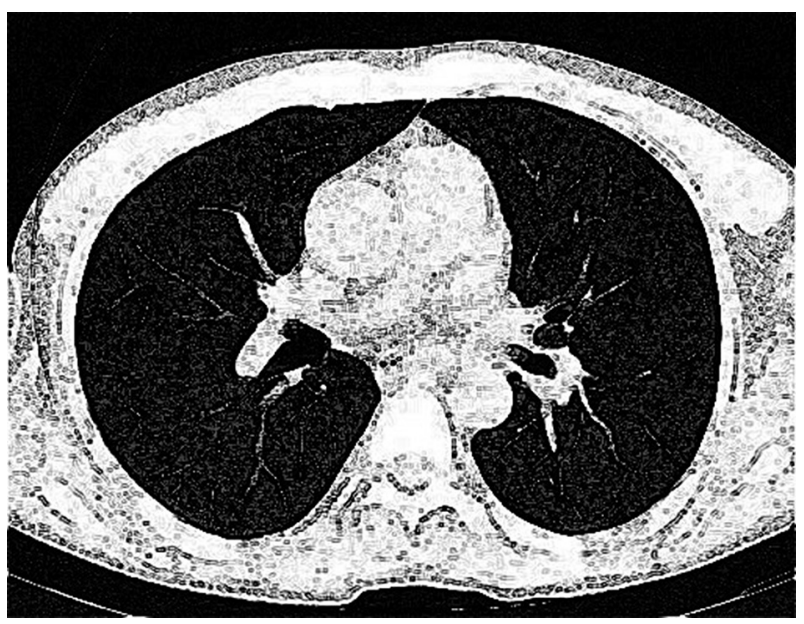

Figure 2. CT scan showing distributed miliary nodules in both lung fields. CT, computed tomography.

(PCR) of the psoas abscesses pus was positive for $M$. tuberculosis.

The TB treatment was continued for 6 months and the patient's progress was favourable and his weight returned to normal and his organomegaly calmed.

\section{Discussion}

Miliary TB is a potentially life-threatening infection if left undiagnosed and treated timely. It can be hard to diagnose forms of extrapulmonary TB. Up to $30 \%$ of TB patients present 


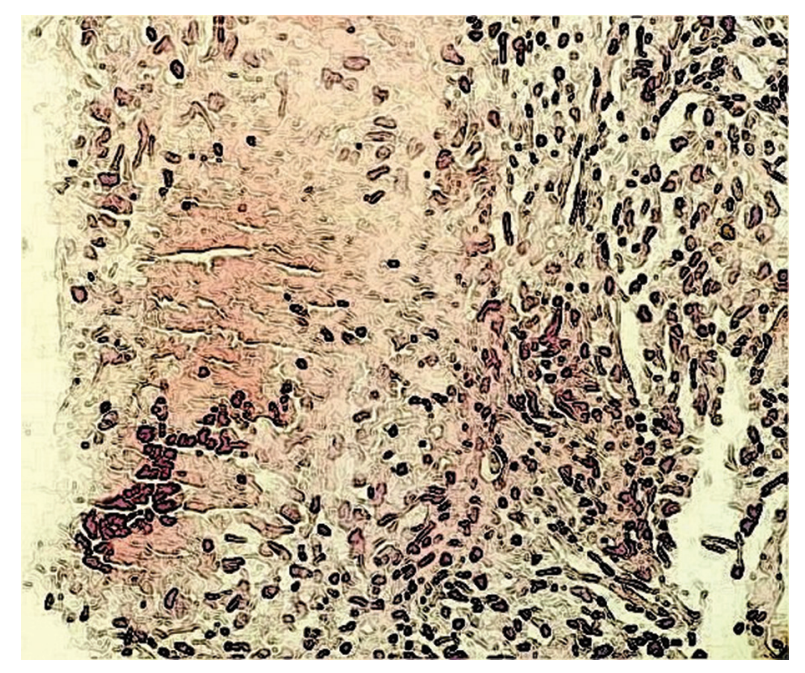

Figure 3. The pathological examination showing a granulomatous reaction with caseous necrosis.

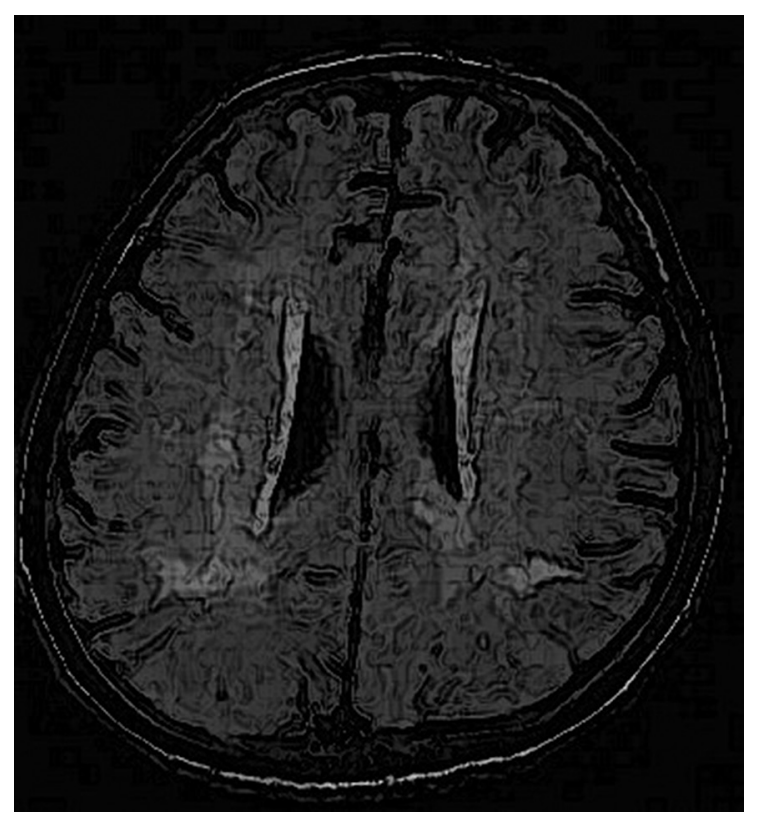

Figure 4. MRI of the brain revealing multi-lobar tuberculomas of the brain. MRI, magnetic resonance imaging.

extrapulmonary involvement (5). Some studies confirmed that the miliary TB accounts for $<2 \%$ of all patients having TB and $>20 \%$ of all extrapulmonary TB patients (6).

Predisposing factors for miliary TB are as follows: old age, diabetes mellitus, chronic renal failure, organ transplantation, malnutrition, corticosteroids, human immunodeficiency virus (HIV) infection, connective tissue disease, immunosuppressive therapy and pregnancy (7). In our case, the predisposition factor was immunosuppressive treatment for secondary organ transplantation.

The clinical and laboratory presentations of miliary TB can be non-specific and highly variable. In miliary TB, haematological abnormalities may include anaemia, leukopenia, leukocytosis, monocytosis, agranulocytosis, thrombocytopenia and pancytopenia $(6,7)$. Also, ESR is typically high. In this case, there were no specific clinical manifestations or laboratory findings suggesting miliary TB except for high ESR.

CXR plays an important role in the initial and final detection of miliary TB (8). Differential diagnoses of pulmonary miliary pattern include histoplasmosis, sarcoidosis, hypersensitivity pneumonia, tumour metastases, bronchogenic carcinoma and pyogenic septic embolisation (9). In case of suspicion of miliary TB, quick diagnostic tests are needed to prove the diagnosis and start the treatment as soon as possible. In our case, CXR and CT scans revealed the presence of miliary nodules distributed in both lungs.

Primary diagnosis of TB relies on the detection of acidfast bacilli. About $<20 \%$ of miliary TB patients underwent a positive sputum smear (10). In this case, acid-fast bacilli were found neither in the spinal bone biopsy nor in the BAL, but a bronchial biopsy revealed caseating granulomas, which is usually required to make a rapid diagnosis.

Molecular techniques, such as PCR, have provided a new approach to the rapid diagnosis of TB (11). As it was reported in our patient who had psoas drainage abscess, PCR is positive for TB. Skeletal TB is diagnosed in about $3 \%$ of all patients, half of whom are due to spinal TB (12).

In our case, the clinical presentation and pulmonary infiltrates combined with radiographic findings of paraspinal abscess were consistent with TB, which was confirmed by molecular and pathologic findings.

The involvement of TB in the central nervous system (CNS) is infrequent. Symptoms may vary, including meningism, nausea, vomiting, headache, papillary oedema, hemiplegia, hemiparesis, monoplegia, aphasia, cerebellar symptoms, epilepsy, seizures and impaired consciousness (13). Our patient presented with pulmonary and cerebral TB several days after his skeletal complaints.

Widespread miliary pulmonary TB has been associated with almost all presented patients with miliary brain tuberculomas, encountered similarly in our patient. Therefore, radiological screening for the CNS is mandatory in all miliary TB cases. Multiple CNS tuberculoma is frequently reported in the HIV infection (14). Our patient was diagnosed with miliary TB but was seronegative for HIV infection. This condition may be due to his immunodeficient state due to immunosuppressive therapy. Also, this case reminds us that it is necessary to check transplant recipients for latent TB with tuberculin skin test (TST) and interferon gamma release assay (IGRA) to 
prevent its activation during the immunosuppressive period, especially in endemic areas of the world for TB.

\section{Conclusion}

This case report may remind us of the importance of maintaining a high level of clinical suspicion and conducting a thorough review for an early diagnosis of miliary TB. In addition, this case also warns us of the importance of initiating timely TB treatment in the cases high- risk TB cases.

\section{Acknowledgement}

The authors thank the Department of Infectious diseases of Babol University of Medical Sciences, Iran.

\section{Ethics approval and consent to participate}

Informed consent for publication was obtained from the patient.

\section{Competing interests}

The authors declare that they have no competing interests.

\section{References}

1. Fishman JA. Infection in organ transplantation. American Journal of Transplantation. 2017;17: 856-879.

2. Anand M, Nayyar E, Concepcion B, Salani M, Schaefer H. Tuberculosis in kidney transplant recipients: a case series. World Journal of Transplant. 2017;7: 213-221.

3. Boubaker K, Gargah T, Abderrahim E, Abdallah TB, Kheder A. Mycobacterium tuberculosis infection following kidney transplantation. BioMed Research International. 2013;2013: 347103.
4. Canet E, Dantal J, Blancho G, Hourmant M, Coupel S. Tuberculosis following kidney transplantation: clinical features and outcome. A French multicentre experience in the last 20 years. Nephrology Dialysis Transplantation. 2011;26: 37733788.

5. Ramirez-Lapausa M, Menendez-Saldana A, NogueradoAsensio A. Extrapulmonary tuberculosis: an overview. Revista Española de Sanidad Penitenciaria. 2015;17: 3-11.

6. Ray S, Talukdar A, Kundu S, Khanra D, Sonthalia N. Diagnosis and management of miliary tuberculosis: current state and future perspectives. Therapeutics and Clinical Risk Management. 2013;9: 9-26.

7. Mert A, Arslan F, Kuyucu T, Koç EN, Ylmaz M, Turan D, et al. Miliary tuberculosis: epidemiological and clinical analysis of large-case series from moderate to low tuberculosis endemic Country. Medicine (Baltimore). 2017;96: e5875. doi: 10.1097/ MD.0000000000005875.

8. Khan F. Review of literature on disseminated tuberculosis with emphasis on the focused diagnostic workup. Journal of Family and Community Medicine. 2019;26: 83-91.

9. Kimmig L, Bueno J. Miliary nodules: not always tuberculosis Annals of the American Thoracic Society. 2017;14: 1858-1860.

10. Sharma SK, Mohan A, Sharma A. Challenges in the diagnosis and treatment of miliary tuberculosis. Indian Journal of Medical Research. 2012;135: 703-730.

11. Neshani A, Kamali Kakhki R, Sankian M, Zare H, Hooshyar Chichaklu A, Sayyadi M, et al. Modified genome comparison method: a new approach for identification of specific targets in molecular diagnostic tests using Mycobacterium tuberculosis complex as an example. BMC Infectious Diseases. 2018;18: 517. doi: 10.1186/s12879-018-3417-x.

12. Faroug $R$, Psyllakis $P$, Gulati A, Makvana $S$, Pareek $M$, Mangwani J. Diagnosis and treatment of tuberculosis of the foot and ankle - a literature review. The Foot. 2018;37: 105-112.

13. Kuo VC, Sloan LM, Emmett M. Central nervous system tuberculosis. Proceedings (Baylor University. Medical Center). 2010;23: 359-360.

14. Nelson CA, Zunt JR. Tuberculosis of the central nervous system in immunocompromised patients: HIV infection and solid organ transplant recipients. Clinical Infectious Diseases. 2011;53: 915-926. 